Original Article

\title{
HEPATOPROTECTIVE ACTIVITY OF ETHANOLIC STEM BARK EXTRACT OF KNEMA ATTENUATA (HOO K. F. AND THOMSON) WARB
}

\author{
SUPRIYA RAJA H. ${ }^{*}$ \\ Department of Pharmacology, College of Pharmaceutical Sciences, Govt Medical College, Trivandrum \\ Email: sraja968@gmail.com
}

Received: 05 May 2020, Revised and Accepted: 29 Jul 2020

\begin{abstract}
Objective: To investigate the hepatoprotective activity of ethanolic stem bark extract (ESBE) of Knema attenuata against carbon tetrachloride (CCl $\left.{ }_{4}\right)$ induced hepatotoxicity in Wistar rats using both in vivo and in vitro models.

Methods: Animals were treated orally with ESBE $\left(250 \mathrm{mg} \mathrm{kg}^{-1}\right.$ and $\left.500 \mathrm{mg} \mathrm{kg}^{-1}\right)$ once daily for $6 \mathrm{~d}$ and $\mathrm{CCl}_{4}$ on the $4^{\text {th }} \mathrm{d}$. On the $7^{\text {th }} \mathrm{d}$, animals were sacrificed and the blood samples were collected to measure the serum levels of biochemical parameters, whereas the liver homogenates were utilized for estimating the antioxidant defense. The hepatoprotective efficacy of the extract was further ensured in vitro using human liver hepatocellular carcinoma (HepG2) cell line against $\mathrm{CCl}_{4}$ induced toxicity. The cell line viability was determined using 3-(4,5-dimethyl thiazol-2-yl)2,5-diphenyl tetrazolium bromide (MTT) assay.

Results: ESBE effectively reduced $(\mathrm{p}<0.001)$ the elevated serum levels of Alanine aminotransferase $($ ALT), Aspartate aminotransferase $($ AST), and Alkaline phosphatase (ALP) when compared to the toxicant control group. ESBE $500 \mathrm{mg} \mathrm{kg}^{-1}$ significantly raised the antioxidant defense (p<0.0001) by reducing the malondialdehyde (MDA) level and enhancing hepatic reduced glutathione (GSH) level in comparison to the $\mathrm{CCl}_{4}$ control group. The in vitro effect was investigated using $\mathrm{CCl}_{4}$ exposed HepG2 cells. Pretreatment with ESBE showed a dose-dependent increase in percentage cell viability ranged between 44 to $57 \%$ at $12.5-100 \mu \mathrm{g} \mathrm{ml}^{-1}$ concentrations $(\mathrm{p}<0.001$, when compared to the control cells).
\end{abstract}

Conclusion: Present study confirms the hepatoprotective activity of the stem bark extract of $K$. attenuata against $\mathrm{CCl}_{4}$-induced liver damage.

Keywords: Knema attenuata, Hepatoprotective, Carbon tetrachloride, MTT assay, Oxidative stress

(C) 2020 The Authors. Published by Innovare Academic Sciences Pvt Ltd. This is an open access article under the CC BY license (http://creativecommons.org/licenses/by/4.0/) DOI: http://dx.doi.org/10.22159/ijpps.2020v12i9.38172. Journal homepage: https://innovareacademics.in/journals/index.php/ijpps.

\section{INTRODUCTION}

The liver, a vital internal organ of the human body, is involved in detoxification and excretion of a majority of xenobiotics, which may cause potential harm to the body. Since it is involved in the biochemical conversions of various endogenous and exogenously administered or ingested substances, highly reactive free radical species may generate $[1,2]$. It has an inbuilt protective mechanism (antioxidants) to neutralize them. However, the imbalance in the liver caused by the difference in the production of free radicals and their elimination by protective mechanisms leads to liver toxicity or damage. During liver damage, free radicals can induce the generation of Pro-inflammatory genes, whose over-expression triggers an intracellular signaling cascade that leads to the production of more free radicals. These pathways could result in enhanced oxidative stress and inflammatory lesions, which promote the pathogenesis of liver diseases [3]. Continuous exposures towards environmental toxins, poor drug habits, and alcohol, can exaggerate the condition, which eventually leads to liver diseases such as hepatitis and jaundice. Due to the adverse effects produced by allopathic medicine, the development of effective therapies using herbal preparations is preferred to treat liver ailments [4].

$\mathrm{CCl}_{4}$ induced hepatotoxicity; a free radical-mediated cytotoxic model is widely employed for the screening of hepatoprotective activity of compounds. The changes associated with $\mathrm{CCl}_{4}$ induced liver damage to resemble that of acute viral hepatitis [5].

K. attenuata, which belongs to Myristicaceae family, is an endemic tree species native to south India extending from Konkan southwards of Maharashtra, Goa, Karnataka, Tamil Nadu, and Kerala [6]. The species has been used in folk medicine as an ingredient of ayurvedic 'Ashwagandhadi nei', for the treatment of conditions like spleen disorders, breathing disorders, and impaired taste sensation. The stem bark is also being used in the form of decoction for the treatment of jaundice and chronic fever [7]. Studies on the stem bark of $K$. attenuata reported the presence of a lignan attenuol; closely related to those isolated from the plants of Myristicaceae family, which are known to possess antioxidant, liver protection, anti-inflammatory and anticancerous properties [8, 9]. Antioxidant, anti-inflammatory, and antimicrobial properties of ethanolic extract of stem bark of $K$. attenuata have already been reported [10-12]. However, there is no scientific work has been performed so far on the hepatoprotective activity of the plant. Therefore, the present study was designed to evaluate the hepatoprotective properties of the ethanolic stem bark of $K$. attenuata using both in vivo and in vitro screening techniques.

\section{MATERIALS AND METHODS}

\section{Collection of plant material}

The stem bark of $K$. attenuata for the proposed study was collected from Kerala Forest Research Institute, Peechi, Thrissur in January 2015. The identification and authentication of species were carried out by Dr. V. B Sreekumar, Scientist (Botany Department), Kerala Forest Research Institute, Peechi, Thrissur. The fresh stem barks were collected, thoroughly washed, spread in trays, and air-dried for three w. The cleaned and air-dried barks were subjected to coarse powdering and sieved (sieve no: 44) to obtain a uniform size for extraction [13].

\section{Preparation of extract}

A $50 \mathrm{~g}$ of dried stem bark powder of $K$. attenuata was packed in a thimble and loaded in a soxhlet apparatus. After defatting stem bark powder with petroleum ether $\left(60-80{ }^{\circ} \mathrm{C}\right)$, it was subjected to continuous extraction with $300 \mathrm{ml}$ of $95 \%$ ethanol to get an ethanolic fraction. The filtrate was evaporated to vacuum (at $40{ }^{\circ} \mathrm{C}$ ) to obtain the dried ESBE with a percentage yield of $17.8 \% \mathrm{w} / \mathrm{w}$. The extract was solubilized using water to feed rats in subsequent studies [14].

\section{Drugs and chemicals}

HepG2 cell lines were purchased from the National Centre for Cell Sciences, Pune. Silymarin and Thiobarbituric acid (TBA) were 
purchased from Sigma chemicals, USA. Dulbecco's modified eagle's medium and Trypsin-EDTA solution were procured from Himedia laboratories, Mumbai. Commercial kits used for determining biochemical parameters were obtained from Agappe Diagnostics Ltd, Kerala. All chemicals and reagents used were of analytical grade.

\section{Animals}

In this study, Wistar rats of either sex (150-250 g), were procured from the animal house (Reg No: 752/02/a/CPCSEA) of Govt. Medical College, Trivandrum. The animals were housed in propylene cages (3 per cage) with dust-free husk as bedding material under standard condition of temperature $\left(25 \pm 2{ }^{\circ} \mathrm{C}\right)$ and relative humidity (30-70\%) with a 12:12 light-dark cycle and fed with standard rodent pellet and water except during experimentation. Institutional Animal Ethics Committee, Govt Medical College, Thiruvananthapuram, approved the experimental protocols on 17/12/2014 (Approval no: 03/13/2014/MCT).

\section{Cell culture}

HepG2 hepatic carcinoma cell lines were maintained in Dulbecco's modified eagle's media supplemented with $10 \%$ Fetal bovine serum (FBS) and grown to confluency at $37{ }^{\circ} \mathrm{C}$ in $5 \% \mathrm{CO}_{2}$ in a humidified atmosphere in a $\mathrm{CO}_{2}$ incubator.

\section{Acute toxicity studies}

Acute oral toxicity test was carried out as per the Organization for Economic Co-operation and Development (OECD) Guidelines for the testing of Chemicals number 425. Since there was little information about the toxicity of extract, the main test was performed. All the animals were observed $14 \mathrm{~d}$ for any sign of toxicity and mortality [15].

\section{Hepatoprotective activity}

Wistar rats of either sex (150-250 g) were randomly divided into 5 groups with each group consisting of 6 animals. Animals of group 1 served as control and were given only vehicle (water) for $6 \mathrm{~d}$ animals of group 2 served as toxin control and were administrated with $\mathrm{CCl}_{4}$ (in liquid paraffin, $1 \mathrm{ml} \mathrm{kg}^{-1}$ orally) on $4^{\text {th }} \mathrm{d}$ and with the vehicle on rest of the $d$. Animals of group 3 received standard drug of silymarin (100 mg kg-1, orally) for $6 \mathrm{~d}$ orally as well as $\mathrm{CCl}_{4}(1 \mathrm{ml} \mathrm{kg}$ $\left.{ }^{1}\right)$ on $4^{\text {th }} \mathrm{d}$. Animals of group 4 and group 5 received ESBE $250 \mathrm{mg} \mathrm{kg}$ 1 , ESBE $500 \mathrm{mg} \mathrm{kg}^{-1}$ for $6 \mathrm{~d}$ orally, and $\mathrm{CCl}_{4}\left(1 \mathrm{ml} \mathrm{kg}^{-1}\right)$ on $4^{\text {th }} \mathrm{d}$.

On $7^{\text {th }} \mathrm{d}$, animals were sacrificed by cervical dislocation. The blood was collected by cardiac puncture of each animal and serum was separated, which was analyzed for assessment of enzyme activity. After collecting blood from each animal, the liver was separated, washed with ice-cold PBS and soaked in filter paper. Liver tissue was minced; added $5 \mathrm{ml}$ ice-cold PBS and was homogenized in tissue homogenizer at $4000 \mathrm{rpm}$ for $5 \mathrm{~min}$ and then centrifuged at 5000 $\mathrm{rpm}$ for $5 \mathrm{~min}$. The clear supernatant was stored at $4{ }^{\circ} \mathrm{C}$ until use $[16,17]$.

\section{Estimation of serum biochemical parameters}

Serum biochemical parameters were estimated according to standard methods. The activity of the enzymes ALT, AST, and ALP was measured using commercial enzymatic biochemical diagnostic kits.

\section{Estimation of tissue biochemical parameters}

\section{a) Lipid peroxidation}

The extent of lipid peroxidation in the liver was determined in supernatant of liver tissue homogenate following standard methodology [18]. The amount of MDA was measured by reaction with TBA at $532 \mathrm{~nm}$ and the MDA level was expressed as nmol mgprotein.

\section{b) Estimation of GSH levels}

GSH level was estimated according to the method described by Ellman GL [19]. The sulfhydryl group of GSH reacts with DTNB (5,5'dithio-bis-2-nitrobenzoic acid, Ellman's reagent) and produces a yellow colored 5-thio-2-nitrobenzoic acid (TNB) with a maximum absorbance at $412 \mathrm{~nm}$. The results were expressed as $\mathrm{nmol} \mathrm{mg}^{-1}$ protein.

\section{In vitro hepatoprotective activity against $\mathrm{CCl}_{4}$ induced HepG2 cell toxicity}

HepG2 hepatic carcinoma cells were trypsinized (500 $\mu$ l of $0.025 \%$ Trypsin in PBS/0.5 mmol EDTA solution) for $2 \mathrm{~min}$ and transferred to $\mathrm{T}$ flasks in complete aseptic conditions. $200 \mu \mathrm{l}$ of the cell suspension was plated into a 96-well culture plate and incubated for $24 \mathrm{~h}$. Post incubation, the cells were treated with different fractions of ESBE at a concentration ranging from (12.5-100 $\left.\mu \mathrm{g} \mathrm{ml}^{-1}\right)$ for $24 \mathrm{~h}$, to investigate the possible toxic effect. MTT assay was employed to measure cell viability. Later, for studying the hepatoprotective activity, cells were pretreated with different fractions of ESBE and incubated for $2 \mathrm{~h}$. Then $\mathrm{CCl}_{4}(0.1 \%)$ was added to the wells and kept for $24 \mathrm{~h}$. Untreated cells were kept as control. Thereafter, the viability of HepG2 cells was estimated by MTT reduction assay [20].

\section{MTT assay}

The cells were washed with $1 \mathrm{x}$ PBS and then added $30 \mu \mathrm{l}$ of MTT solution to the culture (MTT- $5 \mathrm{mg} \mathrm{ml}^{-1}$ dissolved in PBS). It was then incubated at $37{ }^{\circ} \mathrm{C}$ for $3 \mathrm{~h}$. MTT was removed by washing with $1 \mathrm{x}$ PBS and $200 \mu \mathrm{l}$ of DMSO was added to the culture. Incubation was done at room temperature for $30 \mathrm{~min}$ until the cell got lysed and the color was obtained. The solution was transferred to centrifuge tubes and centrifuged at top speed for $2 \mathrm{~min}$ to precipitate cell debris. Optical density was read at $540 \mathrm{~nm}$ using DMSO as blank in a microplate reader $[17,21]$.

$$
\mathrm{V} \%=\left[\frac{\left(O D_{t}-O D_{b}\right)}{\left(O D_{c}-O D_{b}\right)}\right] \times 100
$$

Where, $\mathrm{V} \%$ is percentage cell viability; $\mathrm{OD}_{\mathrm{t}}$ is the optical density of treated cells; $\mathrm{OD}_{\mathrm{b}}$ is optical density of blank cells; and $\mathrm{OD}_{\mathrm{c}}$ is optical density of control cells.

\section{Statistical analysis}

The obtained data were analyzed by one-way ANOVA followed by Dunnet's t-test and $\mathrm{p}<0.05$ was considered statistically significant.

\section{RESULTS}

\section{Acute toxicity studies}

Neither toxic symptoms nor mortality was observed throughout the observation period even at the highest dose (5000 mg kg-1) indicating low toxicity of extract. There were also no significant changes in food consumption, water uptake, and body weight observed in animals after treatment with the stem bark extract of $K$. attenuata. Additionally, the histopathological analysis of vital organs (data not shown) also didn't show statistically significant changes upon the treatment. The results imply that (supported by results from AOT425 stat program version 1.0) that the oral lethal dose $\left(\mathrm{LD}_{50}\right.$ ) of $K$. attenuata is greater than $5000 \mathrm{mg} \mathrm{ml}^{-1}$.

\section{Hepatoprotective effect of ESBE in $\mathrm{CCl}_{4}$-induced liver damage \\ Effect of ESBE on liver function parameters}

Hepatic injury by $\mathrm{CCl}_{4}$ was confirmed by measuring the activity of hepatic marker enzymes ALT, AST, and ALP of rats intoxicated by $\mathrm{CCl}_{4}$. A significant increase in the levels of ALT, AST, and ALP was observed in $\mathrm{CCl}_{4}$-treated rats from those of the control group (fig. 1). Administration of ESBE (250 mg kg-1 and $\left.500 \mathrm{mg} \mathrm{kg}^{-1}\right)$ significantly attenuated the elevation of these parameters in a dose-dependent manner. The hepatoprotective effect shown by ESBE was almost comparable to that of silymarin.

\section{Effect of ESBE on liver oxidative status}

As illustrated in table 1, the MDA level was significantly increased in the $\mathrm{CCl}_{4}$ group as compared to the control group. Silymarin $100 \mathrm{mg}$ $\mathrm{kg}^{-1}$ showed significant protective activity against $\mathrm{CCl}_{4}$-mediated lipid peroxidation. Pretreatment of rats with ESBE at doses of 250 and $500 \mathrm{mg} \mathrm{kg}^{-1}$ also caused a significant diminution of elevated MDA level, indicating that ESBE could effectively inhibit the lipid peroxidation induced by $\mathrm{CCl}_{4}$. Besides, the decrease in the content of GSH caused by $\mathrm{CCl}_{4}$ was effectively reversed by ESBE in a dosedependent manner. 


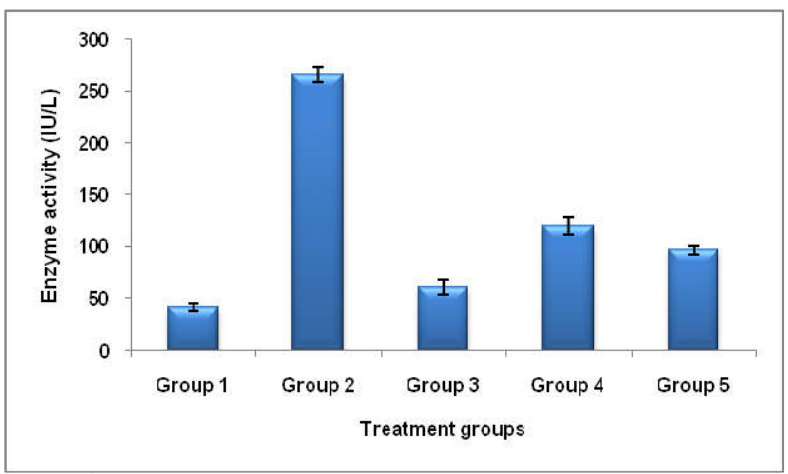

Fig. 1: Effects of ESBE of $K$. attenuata on serum levels of ALT in $\mathrm{CCl}_{4}$-treated wister rats. $\mathrm{n}=6$; Values were expressed in mean \pm standard error of the mean. Silymarin $100 \mathrm{mg} \mathrm{kg}^{-1}$, ESBE $250 \mathrm{mg} \mathrm{kg}^{-1}$, and $500 \mathrm{mg} \mathrm{kg}^{-1}$ were compared to toxicant control; one-way ANOVA followed by Dunnett's t-test. $\mathbf{p}<\mathbf{0 . 0 0 1}$ as compared to the toxicant control group

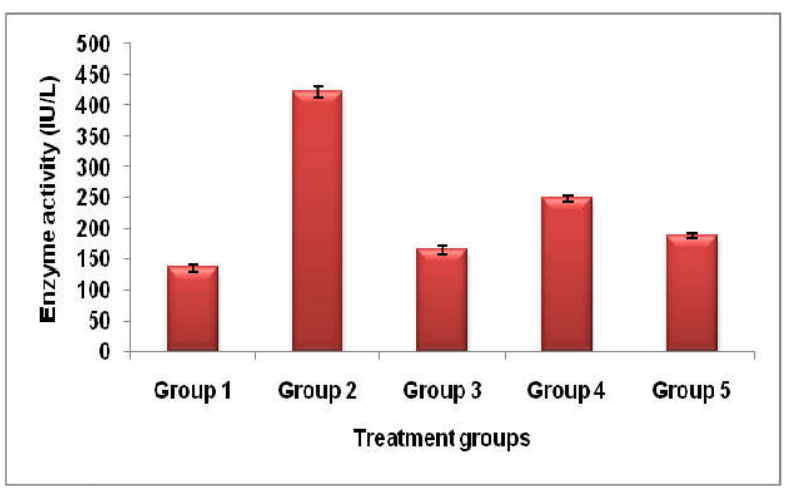

Fig. 2: Effects of ESBE of $K$. attenuata on serum levels of AST in $\mathrm{CCl}_{4}$-treated wister rats. $\mathrm{n}=6$; Values were expressed in mean \pm standard error of the mean. Silymarin $100 \mathrm{mg} \mathrm{kg}^{-1}$, ESBE $250 \mathrm{mg} \mathrm{kg}^{-1}$, and $500 \mathrm{mg} \mathrm{kg}^{-1}$ were compared to toxicant control; one-way ANOVA followed by Dunnett's t-test. Silymarin $100 \mathrm{mg} \mathrm{kg}^{-1}$, ESBE $250 \mathrm{mg} \mathrm{kg}^{-1} ; \mathrm{p}<0.01$ and ESBE $500 \mathrm{mg} \mathrm{kg}^{-1} \mathrm{p}^{-0.001}$ as compared to the toxicant control group

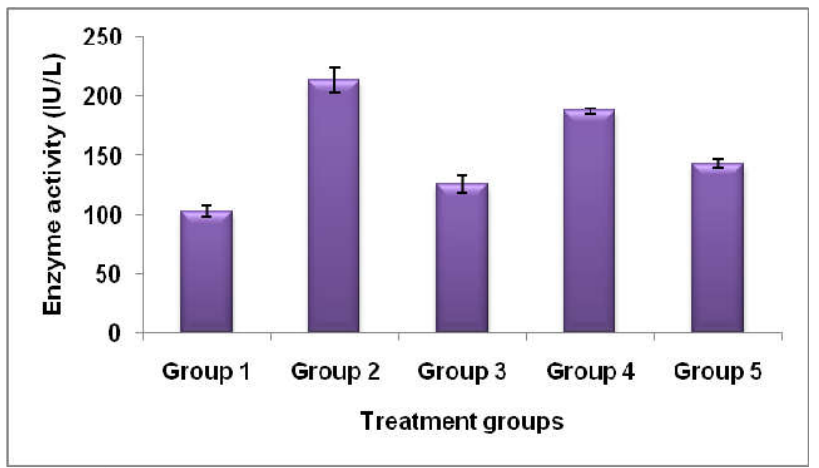

Fig. 3: Effects of ESBE of $K$. attenuata on serum levels of ALP in $\mathrm{CCl}_{4}$-treated wister rats. $\mathrm{n}=6$; Values were expressed in mean \pm standard error of the mean. Silymarin $100 \mathrm{mg} \mathrm{kg}^{-1}$, ESBE $250 \mathrm{mg} \mathrm{kg}^{-1}$, and $500 \mathrm{mg} \mathrm{kg}^{-1}$ were compared to toxicant control; one-way ANOVA followed by Dunnett's t-test. $\mathbf{p}<\mathbf{0 . 0 0 1}$ as compared to the toxicant control group

Table 1: Determination of oxidative stress in liver homogenate, $n=6$; Values were expressed in mean \pm standard error of the mean. ${ }^{* * * *} \mathbf{p}<0.0001,{ }^{* * *} \mathrm{p}<0.001$ compared to $\mathrm{CCl}_{4}$ control group

\begin{tabular}{lll}
\hline Group & GSH (nmol mg $\mathbf{~}^{-1}$ liver) & MDA(nmol mg liver $)^{-1}$ \\
\hline Group 1 & $147.93 \pm 23.71$ & $3.08 \pm 0.06$ \\
Group 2 & $74.76 \pm 7.15$ & $6.34 \pm 0.04$ \\
Group 3 & $138.89 \pm 6.07^{* * *}$ & $3.67 \pm 0.11^{* * * *}$ \\
Group 4 & $113.17 \pm 2.52^{* * * *}$ & $4.96 \pm 0.05^{* * * *}$ \\
Group 5 & $129.61 \pm 3.14^{* * * *}$ & $4.12 \pm 0.15^{* * *}$ \\
\hline
\end{tabular}




\section{In vitro hepatoprotective activity using HepG2 cell lines}

The exposure of HepG2 cells to varying concentrations of ESBE of $K$ attenuata alone for $24 \mathrm{~h}$ did not alter the viability (fig. 4). Upon toxicant administration, the $\mathrm{CCl}_{4}$ exposed cells showed the percentage viability of $22.49 \%$. These exposed cells, when treated with different concentrations of extract, a dose-dependent increase in percentage viability that ranged between $44.33-57.41 \%$ was observed, indicating that pre-treatment with ESBE has considerably prevented cell death in a concentration-dependent manner. The results of cell viability are depicted in table 2 .

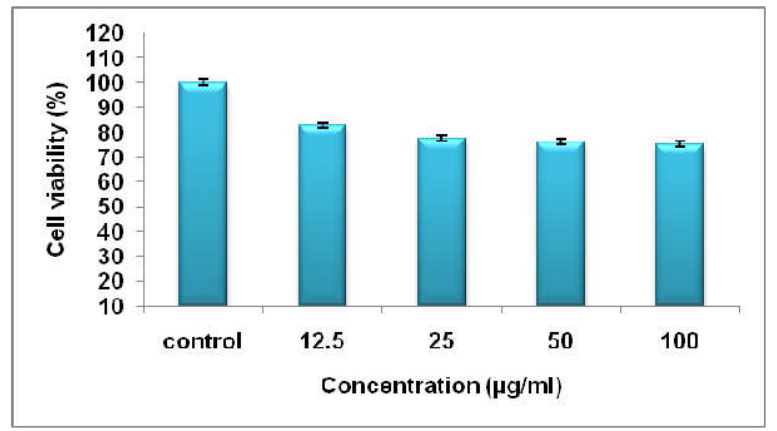

Fig. 4: Effects of ESBE of $K$. attenuata on HepG2 cell viability. $n=3$; values were expressed in mean \pm standard error of the mean

Table 2: The percentage cell viability after drug administration, an average of 3 determinations, carried out in triplicates, values were expressed in mean \pm standard error of the mean, ${ }^{* * *} p<0.001$ compared to control group

\begin{tabular}{lll}
\hline Groups & Treatment & Percentage cell viability (\%) \\
\hline Control & Untreated cells & 100 \\
Toxicant control & $\mathrm{CCl}_{4}(0.1 \%)$ & $22.49 \pm 0.871$ \\
Cells treated with toxicant and Standard & $\mathrm{CCl}_{4}$ with Silymarin $100 \mu \mathrm{g} \mathrm{ml}^{-1}$ & $80.35 \pm 2.05$ \\
Cells treated with toxicant and ESBE & $\mathrm{CCl}_{4}$ with ESBE $12.5 \mu \mathrm{g} \mathrm{ml}^{-1}$ & $44.33 \pm 1.21^{* * *}$ \\
& $\mathrm{CCl}_{4}$ with ESBE $25 \mu \mathrm{g} \mathrm{ml}^{-1}$ & $45.25 \pm 2.61^{* * *}$ \\
& $\mathrm{CCl}_{4}$ with ESBE $50 \mu \mathrm{g} \mathrm{m}^{-1}$ & $52.08 \pm 1.77^{* * *}$ \\
& $\mathrm{CCl}_{4}$ with ESBE $100 \mu \mathrm{g} \mathrm{ml}^{-1}$ & $57.41 \pm 2.33^{* * *}$ \\
\hline
\end{tabular}

\section{DISCUSSION}

Natural products isolated from medicinal plants have gained significance and immense popularity in the modern health care system. Herbal drugs, which offer protection from hepatic disturbances or help in the regeneration of hepatic cells, come under hepatoprotective agents. These drugs contain a variety of chemical constituents like phenols, coumarins, curcuminoids, lignans, essential oils, and terpenoids [22]. The present study demonstrates the effect of ESBE as a possible hepatoprotective agent.

According to the guidelines recommended by OECD, acute oral toxicity testing of crude ESBE was carried out to find the safety profile and the $\mathrm{LD}_{50}$ value for the extract based on which dose for further studies can be selected. As per the study, $\mathrm{LD}_{50}$ value was obtained as greater than $5000 \mathrm{mg} \mathrm{kg}^{-1}$, indicating that the extract was relatively non-toxic [15] Two doses $250 \mathrm{mg} \mathrm{kg}^{-1}$ and $500 \mathrm{mg} \mathrm{kg}^{-1}$ were selected for carrying out the screening of hepatoprotective activity.

$\mathrm{CCl}_{4}$ is a hepatotoxic compound that causes severe hepatic injury. The compound undergoes metabolism by the action of the enzyme cytochrome p 450 forming unstable and highly reactive free radicals such as tri-chloro-methyl $\left(\mathrm{CCl}_{3}-\right)$ and tri-chloro-methyl peroxy radical $\left(\mathrm{CCl}_{3} \mathrm{OO}-\right)$. Hepatotoxicity induced by $\mathrm{CCl}_{4}$ involves the action of these free radicals, which alters the permeability of hepatic cell membrane, causing leakage of liver enzymes such as ALT, AST, and ALP into the blood circulation. Therefore, elevated levels of these liver enzymes are important biomarkers that indicate hepatotoxicity or injury to the liver $[23,24]$. Pre-treatment with ESBE before the introduction of $\mathrm{CCl}_{4}$ has shown a promising dose-dependent potential to restrain the elevated level of liver enzymes in the serum.

Free radicals generated by $\mathrm{CCl}_{4}$ induce substantial oxidative stress and attack polyunsaturated hepatic membrane lipids causing lipid peroxidation. The end products of this oxidation are MDA, 4hydroxynonenal, and 4-hydroxy-2, 3-alkenals [25]. The results obtained indicated elevated MDA levels in the liver as a response to
$\mathrm{CCl}_{4}$ treatment, implying enhanced oxidative damage to the liver. However, the results also suggested that the treatment of $\mathrm{CCl}_{4}$ intoxicated rats with ESBE caused a significant reduction of MDA back to their control levels in the serum.

Glutathione is an antioxidant capable of scavenging free radicals and thereby inhibiting the chain reaction of lipid peroxidation Glutathione can exist in both reduced (GSH) and oxidized (GSSG) states. The sulfhydryl residues of GSH molecule get oxidized to GSSG, which in turn, can be converted back to GSH using glutathione reductase (GR). The redox ratio of GSH/GSSG within cells is a measure of cellular oxidative stress. Therefore, the depletion in the hepatic GSH level indicates the extent of oxidative injury to the liver [26]. The intoxication with $\mathrm{CCl}_{4}$ causes a reduction in the synthesis and functioning of $\mathrm{GSH}$; however, the administration of ESBE reverses this, suggesting a protective effect. Hence, ESBE exhibits antioxidant activity by decreasing the extent of lipid peroxidation and maintaining the glutathione level and thereby relieving oxidative stress.

HepG2 cell line is considered as an effective in vitro model to study the hepatoprotective potential of phyto compounds as they possess functional similarity to normal human hepatocytes [27]. The investigation carried out on HepG2 cells against $\mathrm{CCl}_{4}$-induced damage also confirmed the hepatoprotective nature of ESBE indicating a good correlation between in vivo and in vitro studies.

Phytoconstituents like the phenolic compounds and flavonoids are reported to be present in ESBE, which showed promising antioxidant activity [10]. The mechanism of hepatoprotection exhibited by the ethanolic extract of stem bark of $K$. attenuata can be attributed to their antioxidant potential. ESBE can reduce free radicals that may lessen the oxidative damage to the hepatocytes and improve the activities of the liver antioxidant enzymes, thus protecting the liver from $\mathrm{CCl}_{4}$ induced damage. Its hepatoprotective action can be attributed to the presence of flavonoids and polyphenolic compounds identified in the preliminary phytochemical analysis of extract. 


\section{CONCLUSION}

The stem bark of $K$. attenuata has been used in folk medicine for the treatment of liver disorders. The present study on ESBE of $K$ attenuata shows promising hepatoprotective activity in both in vitro and in vivo studies and thereby provides proper scientific evidence for its traditional use. The study also reaffirms its antioxidant activity, which is due to the presence of flavonoids and phenolic compounds. Therefore, it can also be useful in several diseases that cause oxidative stress. Further work is in progress to isolate and characterize the active constituents responsible for the various pharmacological activities of stem bark of $K$. attenuata.

\section{ACKNOWLEDGEMENT}

The author is grateful to Mr. Suku J, Associate professor (Pharmacology), College of Pharmaceutical Sciences, Trivandrum for his guidance during the study. I acknowledge the guidance and encouragement from Mr. Sreekanth G. B, Scientist-FRM, ICAR Goa for this study.

\section{FUNDING}

$\mathrm{Nil}$

\section{AUTHORS CONTRIBUTIONS}

Conception and design, acquisition, analysis and interpretation of data and writing of the manuscript was carried out by the corresponding author.

\section{CONFLICTS OF INTERESTS}

The author declares no conflicts of interest in preparing this article.

\section{REFERENCES}

1. Akhtar MS, Habib A, Ali A, Bashir S. Isolation, Identification and in vivo evaluation of flavonoid fractions of chloroform/methanol extracts of Rheum emodi roots for their hepatoprotective activity in Wistar rats. Int J Nutr Pharmacol Neurol Dis 2016;6:28-34.

2. Anandan R, Jayakar B, Karar B, Babuji S, Manavalan R, Kumar RS. Effect of ethanol extract of flowers of Vitex trifolia linn. on $\mathrm{CCl}_{4}$ induced hepatic injury in rats. Pak J Pharm Sci 2009;22:391-4.

3. Gordillo KR, Shah R, Muriel P. Oxidative stress and inflammation in hepatic diseases: current $n$ future therapy, Oxid Med Cell Longev 2017. https://doi.org/10.1155/ 2017/3140673

4. Qureshi AA. Evaluation of the antioxidant and hepatoprotective potential of Cinnamomum tamala leaves in rats. Saudi J Health Sci 2015;4:156-62.

5. Bezenjani SN, Pouraboli I, Afshar RM, Mohammadi G Hepatoprotective effect of Otostegia persica boiss. shoot extract on carbon tetrachloride-induced acute liver damage in rats. Iranian J Pharm Sci 2012;11:1235-41.

6. http://www.indiabiodiversityorg/biodiv/species/show/13965 . [Last accessed on 02 Apr 2020]

7. Ravi Kumar K, Ved DK. One hundred red listed medicinal plants of conservation concern in Southern India. Bangalore: Foundation for revitalisation of local health traditions; 2000.

8. Joshi BS, Ravindranath KR, Viswanathan N. Structure and stereochemistry of attenuol, a new lignan from Knema attenuate (Wall) warb. Experientia 1978;34:422.
9. Paul S, Hwang JK, Kim HN, Jeon WK, Chung C, Han JS. Multiple biological properties of macelignan and its pharmacological implications. Arch Pharm Res 2013;36:264-72.

10. Raja HS, Suku J. Phytochemical screening and in vitro antioxidant activity of Knema attenuata (Hook. F. and Thomson) warb stem bark extract. Int J Pharma Sci Res 2019;10:4238-44.

11. Raja HS. Anti-inflammatory activity of Knema attenuata (Hook. F. And Thomson) Warb ethanolic stem bark extract in albino wistar rats. Asian J Pharm Clin Res 2019;12:330-4.

12. Raja HS, Suku J. In vitro evaluation of the antimicrobial activity of Knema attenuata stem bark extract. Indo Am J Pharm Res 2017;7:242-7.

13. Chandrashekhar VM, Ashok A Muchandi, Sarasvathi V Sudi, Seru Ganapty. Hepatoprotective activity of Stereospermum suaveolens against $\mathrm{CCl}_{4}$-induced liver damage in albino rats. Pharm Biol 2010;48:524-8.

14. Li M, Feng X, Deng Baetal DJ. Hepatoprotection of Herpetospermum caudigerum wall against $\mathrm{CCl}_{4}$-induced liver fibrosis on rats. J Ethnopharmacol 2019;229:1-14.

15. https://ntp.niehs.nih.gov/iccvam/suppdocs/feddocs/oecd/oec d_gl425-508.pdf. [Last accessed on 02 Apr 2020]

16. Raj VP, Chandrashekhar $\mathrm{RH}$, Vijayan $\mathrm{P}$. In vitro and in vivo hepatoprotective effects of the total alkaloid fraction of Hygrophila auriculata leaves. Indian J Pharmacol 2010;42:99-104.

17. Joshi BC, Prakash A, Kalia AN. Hepatoprotective potential of potent antioxidant fraction from Urtica dioica linn. (whole plant) in $\mathrm{CCl}_{4}$ challenged rats. Toxicol Rep 2015;2:1101-10.

18. Ohwaka H, Ohishi N, Yagi K. Assay for lipid peroxides in animal tissues by thiobarbituric acid reaction. Anal Biochem 1979;95:351-8.

19. Ellman GL. Tissue sulfhydryl groups. Arch Biochem Biophys 1959;82:70-7.

20. Datta R, Bose S, Mandal SK. Evaluation of in vitro hepatic toxicity of leaves of Pterospermum Acerifolium (L.) willd. Asian J Pharm Clin Res 2020;13:118-20.

21. Talib WH, Mahasneh MA. Antiproliferative activity of plant extracts used against cancer in traditional medicine. Sci Pharm 2010;78:33-45.

22. Qadrie ZLB, Rajkapoor S, Kavimani. Hepatoprotective medicinal herbs and animal models for their screening-a review. Int J Pharma Sci Res 2015;6:5006-28.

23. Hussain F, Malik A, Ayyaz U, Shafique H, Rana Z, Hussain Z. Efficient hepatoprotective activity of cranberry extract against $\mathrm{CCl}_{4}$-induced hepatotoxicity in wistar albino rat model: downregulation of liver enzymes and strong antioxidant activity. Asian Pac J Trop 2017; 10:1054-8.

24. Bouhrim M, Ouassou H, Choukri M, Mekhfi H, Ziyyat A, Legssyer A, et al. Hepatoprotective effect of Opuntia dillenii seed oil on $\mathrm{CCl}_{4}$ induced acute liver damage in rat. Asian Pac J Trop Biomed 2018;8:254-60.

25. Umadevi A, KUMAR PA. In vitro hepatoprotective activity of yellow leaf extracts of Thespesia Populnea against carbon tetrachloride-induced toxicity. Int J Curr 2019;11:21-3.

26. Aoyama K, Nakaki T. Glutathione in cellular redox homeostasis: association with the excitatory amino acid carrier 1 (EAAC1). Molecules 2015;20:8742-58.

27. Shah VN, Shah MB, Bhatt PA. Hepatoprotective activity of punarnavashtak kwath, an Ayurvedic formulation, against $\mathrm{CCl}_{4}$ induced hepatotoxicity in rats and on the HepG2 cell line. Pharm Biol 2011;49:408-15. 